Anna Irena Szymańska

Uniwersytet Pedagogiczny, Kraków

\title{
Innowacyjność produktowa przedsiębiorstw produkcyjnych a preferencje konsumentów
}

Przedsiębiorstwa funkcjonujące na współczesnym, dynamicznie rozwijającym się rynku muszą cechować się innowacyjnością, efektywnością i elastycznością działań. Jednocześnie zwraca się szczególną uwagę na potrzebę sprawnego zarządzania procesami implementacji innowacji. Organizacje innowacyjne muszą cechować się zdolnością do sprawnego wprowadzania nowych produktów, technologii oraz metod organizacji, kluczowych w realizacji zmieniających się celów rozwojowych (Bogdaniecko 2004). Zdaniem P.F. Druckera (Drucker 1992) organizacja musi stworzyć odpowiedni klimat dla innowacji, śledzić efektywność podejmowanych działań, dokonywać modyfikacji struktury organizacyjnej, wypracować system zachęty do zmian.

Efektem działań innowacyjnych jest podniesienie wartości organizacji oraz uzyskania przewagi konkurencyjnej na rynku. Z drugiej jednak strony innowacyjność wiąże się z ponoszeniem przez organizację określonych nakładów finansowych. Podjęcie przez przedsiębiorstwo decyzji o wdrożeniu określonej innowacji powinno więc być poprzedzone przede wszystkim analizą wysokości nakładów finansowych wymaganych do realizacji określonych celów oraz przewidywanych korzyści, będących efektem wdrożenia określonej innowacji.

\section{ZNACZENIE INNOWACYJNOŚCI W KREOWANIU \\ PRZEWAGI KONKURENCYJNEJ PRZEDSIĘBIORSTW}

Działalność innowacyjna prowadzona przez przedsiębiorstwa definiowana jest jako „szereg działań o charakterze naukowym (badawczym), finansowym, technicznym, handlowym i organizacyjnym, których celem jest opracowanie bądź wdrożenie nowych lub istotnie ulepszonych (z punktu widzenia wprowadzającego je przedsiębiorstwa) produktów i procesów" (http://www.stat.gov.pl). Z pojęciem innowacji wiążą się działania skierowane na wprowadzanie zmian zmierzających do wzrostu nowoczesności i konkurencyjności przed- 
siębiorstwa. Innowacją może być więc wprowadzanie nowych produktów, wdrażanie nowych technologii, zmiany infrastruktury produkcyjnej i dystrybucyjnej, efektywniejsze wykorzystanie wiedzy i umiejętności pracowników, czy rozwój sieci informacyjnych.

Samo pojęcie innowacji ${ }^{1}$ wprowadzone zostało do nauk ekonomicznych jeszcze w 1911 roku przez austriackiego ekonomistę J. Schumpetera². Klasyczne, Schumpeterowskie ujęcie innowacji stanowiło punkt wyjścia do dalszych rozważań dotyczących znaczenia innowacyjności w gospodarce. Wraz ze zmieniającą się strukturą i rolą przemysłu koncepcja innowacyjności ewoluowała. $\mathrm{Ph}$. Kotler na przykład traktując innowację z perspektywy marketingu, zdefiniował ją jako dobro, usługę lub pomysł, postrzegane przez kogoś jako nowe. Sam pomysł mógł już istnieć od dawna, jednak stanowił innowację dla osoby postrzegającej go jako nowy (Kotler 1994). Podobnie szerokie ujęcie reprezentował P. Drucker dopuszczając traktowanie jako innowacji każdej nowości. Zdaniem R.W. Griffina innowacją jest kierowany wysiłek organizacji na rzecz opanowania nowych produktów i usług lub nowych zastosowań produktów i usług już istniejących na rynku (Griffin 1996). Natomiast M.E. Porter poszerza pojęcie innowacji o ulepszenia technologiczne, lepsze metody oraz sposoby wykonywania danej rzeczy. Mogą to być również zmiany produktu lub procesu, nowe podejście do marketingu, nowe formy dystrybucji (Porter 1990).

Głównym celem podejmowania przez przedsiębiorstwo działalności innowacyjnej jest realizacja długookresowej strategii rozwoju firmy prowadzącej do zaspokojenia potrzeb klientów, uzyskania pozycji konkurencyjnej na rynku oraz wymiernej korzyści ekonomicznej. Działania te mają więc charakter ekonomiczno-społeczny.

O kluczowym znaczeniu innowacyjności w kreowaniu przewagi konkurencyjnej przedsiębiorstw sygnalizują autorzy wielu opracowań teoretycznych z tego tematu. Można tu wymienić między innymi J. Kay’a, G. Hamela, C.K. Prahalada, M. Portera czy H. Simona.

Zgodnie z koncepcją J. Kay’a (Kay 1996) firma może osiągnąć sukces, jeśli właściwie rozpozna swoje zdolności i wybierze rynek najbardziej do nich dostosowany. Jako jedno z podstawowych źródeł przewagi konkurencyjnej J. Kay wymienił tu właśnie innowacje (pozostałe to architektura, reputacja i zasoby strategiczne). Innowacje mogą odnosić się zarówno do produktu, technologii jak również systemów organizacji i zarządzania. Przyjmując jako kryterium podziału oryginalność J. Kay wymienił innowacje oryginalne oraz imitacje. Innowacje oryginalne stanowią źródło długotrwałej przewagi konkurencyjnej. Natomiast poprzez imitacje przedsiębiorstwo może osiągnąć jedynie nietrwałą przewagę konkurencyjną. Należy tu jednak zwrócić uwagę, że chociaż innowacje oryginalne stanowią podstawę przewagi konkurencyjnej, to jednak w wielu przypadkach problemem jest utrzymanie jej na własność. Ze względu na różnorodność możliwości naśladownictwa często efekty rynkowe są udziałem nie tylko samego pioniera danej innowacji, ale wielu firm.

\footnotetext{
${ }^{1} \mathrm{~W}$ potocznym rozumieniu innowacja oznacza coś nowego i innego od dotychczasowych rozwiązań; kojarzy się z potrzebną zmianą na lepsze. Słowo to pochodzi od łacińskiego innovatio czyli odnowienie (Janasz, Kozioł 2007).

${ }^{2}$ Pojęcie innowacyjności w ujęciu J. Schumpetera obejmowało pięć przypadków: 1. wprowadzenie nowego produktu, z jakim konsumenci nie mieli jeszcze do czynienia, lub nadanie nowych cech produktowi; 2 . wprowadzenie nowej metody produkcji jeszcze praktycznie nie wypróbowanej w danej dziedzinie przemysłu; 3. otwarcie nowego rynku, czyli takiego na którym dany rodzaj krajowego przemysłu uprzednio nie działał $\mathrm{i}$ to bez względu na to, czy rynek istniał wcześniej, czy nie; 4. zdobycie nowego źródła surowców lub półfabrykatów niezależnie od tego, czy źródło to już istniało, czy też musiało być dopiero stworzone; 5. wprowadzenie nowej struktury organizacji jakiegoś przemysłu, np. stworzenie monopolu bądź jego złamanie (Schumpeter 1960).
} 
Koncepcja G. Hamela i C.K. Prahalada (Hamel, Prahalad 1999) akcentuje rolę innowacji w kształtowaniu przewagi konkurencyjnej. Zdaniem autorów wykreowanie w przedsiębiorstwie kluczowych kompetencji umożliwia osiągnięcie długotrwałej przewagi konkurencyjnej. Źródłem tych kompetencji wbrew pozorom nie są nowe technologie, a nowe koncepcje zaspokajania potrzeb odbiorców. Nowatorskie kompetencje przedsiębiorstw zapoczątkowują tworzenie się nowych branż oraz nowych rynków zbytu. Rosnące tempo przemian społecznych, którego efektem jest tworzenie nowych dziedzin, nowych potrzeb oraz głębokie zmiany w tradycyjnych sektorach sprawia, że uzyskanie pozycji lidera na rynku może być możliwe jedynie poprzez kreowanie nowych produktów i usług. Zgodnie z koncepcją G. Hamela i C.K. Prahalada to właśnie innowacyjność jest punktem wyjścia w kreowaniu kluczowych kompetencji przedsiębiorstwa. Wyraża się ona między innymi w definiowaniu określonych obszarów badawczych, opracowywaniu projektów udoskonalania procesów produkcyjnych oraz sprzedażowych prowadzących do zdobycia pozycji lidera rynkowego w długim okresie.

Podobnie jak wyżej wymienieni autorzy, również M. Porter (Porter 2001) podkreśla kluczowe znaczenie innowacyjności w kreowaniu przez przedsiębiorstwo przewagi konkurencyjnej na rynku. Przedsiębiorstwa dążą do wdrażania innowacyjności w jej najszerszym rozumieniu, zarówno poprzez wprowadzanie nowej techniki, jak również nowych sposobów postępowania.

H. Simon (Simon 1999) w swoich badaniach przeprowadzonych na grupie małych i średnich przedsiębiorstw niemieckich dowodzi, że kluczem do ich sukcesu i zdobycia czołowej pozycji na rynku była strategia innowacyjna. Przedsiębiorstwa te osiągnęły przywództwo na rynku poprzez zajęcie pozycji pioniera w jakimś istotnym aspekcie technologii, czy praktyki działania na swoim rynku. H. Simon nazywa te przedsiębiorstwa nieznanymi mistrzami.

Przytoczone powyżej koncepcje i wyniki badań potwierdzają słuszność stwierdzenia, że innowacyjność może stanowić podstawę w budowaniu przewagi konkurencyjnej przedsiębiorstw. Potwierdza to również wiele koncepcji dotyczących strategii przedsiębiorstwa. Jako przykład można tu podać strategię wzrostu przedsiębiorstwa, która została scharakteryzowana w macierzy H.I. Ansoffa produkt-rynek. Innowacyjność produktowa i technologiczna stanowi tu podstawowy warunek pozwalający na jej realizację.

Proces stałego doskonalenia systemu zarządzania przedsiębiorstwem wskazuje na szeroki zakres działań, które należy podjąć, aby osiągnąć poziom konkurencyjności pozwalający zająć silną pozycję na rynku (Grudzewski, Hejduk 2004). Wymaga to zastosowania różnorodnych koncepcji, metod czy technik organizacji i zarządzania przedsiębiorstwem. Obok tych znanych pojawiają się również nowe koncepcje takie jak np. zarządzanie wiedzą, zarządzanie innowacjami, zarządzanie technologiami, czy zarządzanie procesowe. Owa różnorodność oraz szeroki wieloprzekrojowy charakter koncepcji zarządzania umożliwiają lepsze opracowanie sposobów realizacji przyjętych strategii rozwojowych. Jest to szczególnie istotne $\mathrm{z}$ uwagi na fakt, iż przewagi konkurencyjnej przedsiębiorstwa poszukuje się w różnych obszarach funkcjonowania przedsiębiorstwa, np.:

- w obszarze marketingu - dobór nowoczesnych, odpowiednio dopasowanych narzędzi umożliwiających komercjalizowanie nowych produktów, kształtowanie kanałów dystrybucji i relacji z klientami,

- w obszarze produkcji - wykorzystywanie metod wspomagających uruchamianie nowej produkcji, sterowanie produkcją oraz samą produkcję, 
- w obszarze logistyki - kształtowanie łańcuchów dostaw, kreowanie systemów logistycznej obsługi klienta, implementacja nowoczesnych systemów informatycznych usprawniających współpracę i komunikowanie się z klientami i dostawcami,

- w obszarze badań i rozwoju - wykorzystywanie narzędzi wspomagających prace przygotowawcze i rozwojowe,

- w obszarze zarządzania kadrami - stosowanie metod wspomagających właściwy dobór pracowników, ich rozwój, kształtowanie ścieżek rozwoju zawodowego, motywowanie, ocenianie (Pałucha 2008).

\section{TYPOLOGIA INNOWACJI}

Występuje wiele zjawisk dających się opisać pojęciem innowacji i przeanalizować za pomocą aparatu ekonomicznego. Na przykład O. Grandstrand wymienia innowację technologiczną i techniczną, innowację usługową, innowację finansową, innowację organizacyjną/zarządczą, innowację marketingową/dystrybucyjną, innowację instytucjonalną oraz inne typy innowacji jak np. społeczna, prawna, polityczna czy kulturowa (Tabela 1).

Istnieją również typologie w większym stopniu podkreślające podejście zarządcze polegające na identyfikacji innowacji w każdym stadium łańcucha wartości (tj. etapie dostarczania produktów i usług na rynek). W tym przypadku można wymienić np. innowacje produktowe, postęp dotyczący metod produkcji, rozpoznawanie nowych źródeł podaży lub nowych rynków zbytu, wdrażanie nowych sposobów organizacji przedsiębiorstwa. Można również dokonać rozróżnienia na innowacje „twarde” technologiczne oraz „miękkie” organizacyjne. Podział ten podkreśla łatwość identyfikacji efektów działań innowacyjnych w przypadku innowacji twardych oraz trudność owej identyfikacji w przypadku innowacji miękkich. Tym drugim trudno jest niekiedy przypisać pojawiające się efekty niezamierzone.

Tab. 1. Ogólne typy innowacji według O. Grandstranda

\begin{tabular}{|l|l|l|}
\hline \multicolumn{1}{|c|}{ Typ innowacji } & \multicolumn{1}{|c|}{$\begin{array}{c}\text { Cechy praw własności } \\
\text { intelektualnej }\end{array}$} & \multicolumn{1}{c|}{ Komentarze/przykłady } \\
\hline $\begin{array}{l}\text { Technologiczna (zmiana w kon- } \\
\text { tekście wiedzy) } \\
\text { Techniczna (zmiana artefaktów } \\
\text { ucieleśniających wiedzę) }\end{array}$ & $\begin{array}{l}\text { Daje się ochronić patentem/ami } \\
\text { Daje się chronić tajemnicą han- } \\
\text { dlową, prawami autorskimi } \\
\text { (copyright), znakiem handlo- } \\
\text { wym, marką itp. }\end{array}$ & Koło, telefon, tranzystor \\
\hline $\begin{array}{l}\text { Innowacja usługowa (service): } \\
\text { usługi informatyczne, telekomu- } \\
\text { nikacyjne, medyczne, finanso- } \\
\text { we, edukacyjne, itp. }\end{array}$ & $\begin{array}{l}\text { Nie daje się ochronić patentem } \\
\text { (na ogół) } \\
\text { Technologie wspierające (sup- } \\
\text { porting) dają się ochronić pa- } \\
\text { tentem } \\
\text { Daje się chronić tajemnicą } \\
\text { handlową, prawami autorskimi, } \\
\text { znakiem handlowym }\end{array}$ & $\begin{array}{l}\text { Gazeta, transplantacja serca, } \\
\text { nowy kierunek studiów }\end{array}$ \\
\hline
\end{tabular}




\begin{tabular}{|l|l|l|}
\hline Innowacje finansowe & $\begin{array}{l}\text { Nie daje się ochronić patentem } \\
\text { Łatwo daje się imitować, choć } \\
\text { dyfuzja może być powolna }\end{array}$ & $\begin{array}{l}\text { Opcje, papiery zamienne, cer- } \\
\text { tyfikaty depozytowe, polisy } \\
\text { ubezpieczeniowe }\end{array}$ \\
\hline $\begin{array}{l}\text { Innowacje organizacyj- } \\
\text { ne/zarządcze }\end{array}$ & $\begin{array}{l}\text { Nie daje się ochronić patentem } \\
\text { (na ogół) } \\
\text { Daje się chronić tajemnicą } \\
\text { handlową } \\
\text { Dyfuzja bywa powolna }\end{array}$ & $\begin{array}{l}\text { Struktura organizacyjna (np. } \\
\text { dywizjonalna M) } \\
\text { PERT, kanban, just-in-time, } \\
\text { “toyotism”, TQM,... }\end{array}$ \\
\hline $\begin{array}{l}\text { Innowacja marketingowa } \\
\text { /dystrybucyjna }\end{array}$ & $\begin{array}{l}\text { Nie daje się ochronić patentem } \\
\text { Technologie wspierające } \\
\text { (supporting) dają się ochronić } \\
\text { patentem }\end{array}$ & $\begin{array}{l}\text { Supermarket, sprzedaż za } \\
\text { pośrednictwem poczty, } \\
\text { Internetu, tele-marketing }\end{array}$ \\
\hline $\begin{array}{l}\text { Innowacja instytucjonalna się ochronić patentem } \\
\text { Dyfuzja bywa powolna }\end{array}$ & $\begin{array}{l}\text { System patentowy, spółka } \\
\text { z o.o., franczyza, MBA }\end{array}$ \\
\hline $\begin{array}{l}\text { Inne typy: społeczna, prawna, } \\
\text { polityczna, kulturowa } \\
\text { ochronić intelektualnymi prawa- } \\
\text { mi własności (IPR) }\end{array}$ & $\begin{array}{l}\text { Unia Europejska, } \\
\text { Opera, konwencja Gerbera }\end{array}$ \\
\hline
\end{tabular}

Źródło: O. Grandstrand, The Economics and Management of Intellectual Property. Towards Intellectual Capitalism, Edward Elgar, Cheltenham 1999, s. 57; A. Sulejewicz, Innowacje jako dziedzina gospodarowania, [w:] Określenie istoty pojęć: innowacji i innowacyjności ze wskazaniem aktualnych uwarunkowań i odniesień do polityki proinnowacyjnej - podejście interdyscyplinarne, Krajowa Izba Gospodarcza, http://www.kig.pl

Często proponowanym podziałem jest podział na innowacje produktowe, procesowe i usługowe. Należy tu zaznaczyć, że do niedawna wyróżniano głównie innowacje produktowe i procesowe traktując je jako przejaw postępu technologicznego. Wyodrębnienie innowacji usługowych związane jest ze wzrostem znaczenia usług we współczesnej gospodarce rynkowej oraz faktu, iż są one zazwyczaj przejawem postępu technologicznego.

Innowację produktową definiuje się jako wprowadzenie na rynek produktu, którego cechy technologiczne lub przeznaczenie znacząco różnią się od produktów dotąd wytwarzanych lub którego działanie zostało w znacznym stopniu ulepszone i jednocześnie może on dostarczać konsumentowi obiektywnie nowych lub zwiększonych korzyści. Innowacja procesowa jest to wprowadzenie nowych lub w dużej mierze ulepszonych metod produkcji lub dostarczania produktów. Innowacje mogą dotyczyć wprowadzenia zmian w obszarze organizacji przedsiębiorstwa, stosowanych technologii, zasobów ludzkich, metod pracy, sprzętu lub też kombinacji wymienionych zmian (Wiszniewski 1999, s. 9). Natomiast innowacyjność usługowa polega na wprowadzeniu na rynek usługi nowej lub postrzeganej jako nowa, która przynosi konsumentowi nową korzyść lub wartość. Tego typu innowacja wiąże się ze zmianą charakterystyki istniejącej usługi, ewentualnie zaproponowaniem nowej. $\mathrm{W}$ wielu podziałach innowacja usługowa definiowana jest łącznie z innowacją produktową.

\section{INNOWACYJNOŚĆ NA RYNKU NAPOJÓW BEZALKOHOLOWYCH}

Rynkiem, na którym innowacyjność i stałe poszerzanie oferty produktowej odgrywa szczególne znaczenie jest rynek FMCG (Fast Moving Consumer Goods - Rynek Produktów 
Szybko Rotujących). Cechą charakterystyczną produktów tego rynku jest szybka rotacja oraz relatywnie niski koszt produkcji. Rynek produktów szybkozbywalnych jest bardzo trudny, z uwagi na fakt, iż konsumenci dokonując codziennych zakupów muszą dokonywać wyboru produktów spośród co najmniej kilkudziesięciu rodzajów herbat, słodyczy czy napojów bezalkoholowych. Podążając za cechami definiującymi markę, przedsiębiorcy poszerzają swoją ofertę asortymentową, a poszczególnym produktom nadają określoną osobowość, wartości oraz kulturę. Wykorzystują przy tym masowe środki przekazu. Konsumenci natomiast odbierają owe sygnały, a poprzez wybór określonej marki kreują własny wizerunek, własną tożsamość i przekazują ją otoczeniu.

W moich badaniach skoncentrowałam się na innowacjach produktowych a jako obszar badań wybrałam rynek napojów bezalkoholowych w Polsce.

Rynek napojów bezalkoholowych w Polsce stanowi jeden z głównych motorów napędzających przemysł spożywczy. Wzrost znaczenia tego sektora wpływa na wzrost konkurencji oraz wzmożoną aktywność wśród producentów. Przewiduje się, że popyt na napoje bezalkoholowe będzie w Polsce nadal rósł.

Zgodnie z wynikami badań spożycie napojów w Europie w okresie ostatnich dziesięciu lat zwiększyło się o 22 miliardy litrów. Wartość sprzedaży w Europie w roku 2010 wyniosła 216 miliardów euro i wzrosła o 55 miliardów euro w porównaniu z 2000 rokiem. Polski udział w tych wydatkach wynosi zaledwie około $2 \%$, ale systematycznie rośnie.

Zdaniem ekspertów z Agencji Badań Rynku Canadean do roku 2020 należy spodziewać się wzrostu spożycia napojów bezalkoholowych w Europie do około 131 miliardów litrów rocznie. Oznacza to, że każdy mieszkaniec Europy wypije 259 litrów wody butelkowanej, soków, soft drinków i nektarów w ciągu roku. Zmieni się również geograficzna struktura konsumpcji. Wzrośnie udział krajów Europy Środkowo-Wschodniej, w tym Polski do około 8\%, kosztem między innymi Francji, Hiszpanii i Wielkiej Brytanii (Rutkowski 2010).

Rynek napojów bezalkoholowych w Polsce, charakteryzujący się dużym zróżnicowaniem produktowym sprawia, że konsument ma możliwość jednoczesnego dostarczania niezbędnych ilości płynów oraz zaspokajania własnych zachcianek smakowych. Współcześnie napój to nie tylko ugaszenie pragnienia, ale również coś smacznego, orzeźwiającego, bardzo często to również moda i styl bycia. Producenci próbują sprostać tym wymaganiom poprzez zmianę wizerunku etykiet oraz opakowań, do których wlewany jest napój, czy też zmianę receptury napoju. Obecnie konsument pragnie być zaskakiwany. Nie wystarczy więc tylko smaczny napój. Konieczne są takie rozwiązania jak np. czarne szkło od O-I (Owens-Illinois, Inc.) lub aluminiowa Coca-Cola zaprojektowana przez Karla Lagerfelda, które zwracają na siebie uwagę.

Wielu producentów napojów bezalkoholowych wprowadziło w roku 2010 zmiany dotyczące wizerunku opakowań i etykiet oraz poszerzenia swojego portfolio produktowego. Przykładem może tu być Cisowianka Perlage z nową etykietą z wizerunkiem Fryderyka Chopina, która trafiła do sprzedaży w marcu. Na początku roku pojawiły się również produkty marki Piwniczanka w nowej, odświeżonej formie, podobnie jak i Ustronianka, która wprowadziła do sprzedaży także wodę z dodatkiem jodu. Firma Pepsi Co. dokonała modyfikacji wizualizacji marki Pepsi. Zmieniono zarówno logo, jak również główną czcionkę oraz grafikę na opakowaniach (Krajowa Izba Gospodarcza 2011).

Na początku 2012 roku firma Polskie Zdroje planuje wprowadzenie wody Cisowianka Perlage w puszce. Będzie to pierwsza w Polsce oraz druga w Europie (na chwilę obecną 
w Europie dostępna jest tylko marka Perrier w puszcze) woda mineralna w tym opakowaniu. Dynamiczne zmiany oraz wprowadzane innowacje na rynku napojów w Polsce dowodzą, że walka o klienta cały czas trwa i jest bardzo zacięta.

\section{ANALIZA WYNIKÓW BADAŃ EMPIRYCZNYCH}

\section{Deklarowane preferencje konsumentów w wybranych segmentach rynku}

Określenie poziomu otwartości konsumentów na innowacje dotyczące zmiany wizerunku opakowań jak również poszerzania przez producentów oferty asortymentowej wymagało przeprowadzenia badań empirycznych. W związku z powyższym w listopadzie 2011 roku przeprowadzono marketingowe badania bezpośrednie. Badania dotyczyły zachowań konsumentów na rynku napojów bezalkoholowych, a jako grupę docelową wybrano osoby w wieku do 25 lat.

Rynek napojów bezalkoholowych charakteryzuje się dużą dynamiką rozwoju, wprowadzaniem nowych produktów, smaków, modyfikowaniem receptury i opakowań produktów. Natomiast konsumenci w wieku do 25 lat to grupa najbardziej otwarta na innowacje, nie obawiająca się ryzyka, bezkompromisowa, lubiąca eksperymentować.

Zasadniczym celem badań było zdiagnozowanie motywów, którymi kierują się konsumenci przy wyborze określonej marki napoju, ich otwartości na innowacje produktowe oraz preferowanych przez konsumentów cech produktów determinujących określony wybór.

Przystępując do formułowania aparatu badawczego przyjęto założenie, że analiza preferencji konsumentów oraz motywów, którymi się kierują przy wyborze określonego produktu będzie dotyczyła trzech segmentów rynku napojów bezalkoholowych: napojów gazowanych, wód mineralnych (dominujące segmenty rynku napojów bezalkoholowych), oraz napojów energetycznych i izotonicznych (segment, w którym przeważają konsumenci w przedziale wiekowym do 25 lat).

Z uwagi na ograniczenia czasowe populację generalną stanowili studenci Uniwersytetu Pedagogicznego im. KEN w Krakowie. Próbę dobrano losowo wśród studentów I roku studiów stacjonarnych i niestacjonarnych i stanowiło ją 200 respondentów, przy czym: w 60\% były to kobiety, a w $40 \%$ mężczyźni. Ponadto $70 \%$ próby stanowili mieszkańcy miasta, natomiast 30\% mieszkańcy wsi.

Wyniki badań wskazują na tradycyjne upodobania studentów Uniwersytetu Pedagogicznego w Krakowie w kwestii najczęściej spożywanych napojów. Najbardziej preferowanym napojem okazała się być herbata. Ponad połowa ankietowanych $(53,5 \%)$ zadeklarowała, iż jest ona napojem najczęściej przez nich spożywanym. Woda mineralna była napojem, który wybierany był przez respondentów jako drugi najczęściej spożywany. Grupa stanowiąca ponad 19\% ogółu ankietowanych wybrała wodę mineralną jako najbardziej preferowany napój. Natomiast zaledwie $8 \%$ ankietowanych wybrało napoje gazowane jako najczęściej spożywany napój.

Zgodnie z założeniami wstępnymi dalszej analizie poddano trzy segmenty rynku napojów bezalkoholowych. Wyniki badań wykazały, iż aż $90 \%$ spośród badanych pije wodę 
mineralną, ponad $75 \%$ respondentów pije napoje gazowane, a $45 \%$ spożywa napoje energetyczne i izotoniczne.

Szczegółowa analiza segmentu napojów gazowanych wykazała, że najczęściej wybieranymi przez respondentów markami były Pepsi (59,6\%), Coca-Cola $(50,3 \%)$, Sprite $(39,7 \%)$ i Fanta $(39,7 \%)$.

Tab. 2. Preferencje konsumentów dotyczące marek spożywanych napojów gazowanych

\begin{tabular}{|l|c|c|}
\hline \multirow{2}{*}{$\begin{array}{c}\text { Marki napojów gazowanych } \\
\text { N=151 }\end{array}$} & Liczność & Procent przypadków* \\
\cline { 2 - 3 } & 76 & 50,3 \\
\hline Coca-Cola & 6 & 4,0 \\
\hline Coca-Cola light & 4 & 2,6 \\
\hline Coca-Cola zero & 60 & 39,7 \\
\hline Fanta & 69 & 45,7 \\
\hline Sprite & 90 & 59,6 \\
\hline Pepsi & 21 & 13,9 \\
\hline Pepsi twist & 14 & 9,3 \\
\hline Miriada & 15 & 9,9 \\
\hline 7 Up & 9 & 6,0 \\
\hline Schweppes & 11 & 7,3 \\
\hline Hoop cola & 36 & 23,8 \\
\hline 3 cytryny & 2 & 1,3 \\
\hline Slice & 413 & 273,5 \\
\hline Razem & & \\
\hline
\end{tabular}

*Z uwagi na fakt, iż każdy z respondentów miał możliwość udzielenia trzech odpowiedzi, a w pewnych przypadkach nie udzielono żadnej odpowiedzi, suma wartości w kolumnie „\%” nie jest równa 100

Źródło: badania własne na podstawie programu STATISTICA 9

Natomiast marki napojów gazowanych najrzadziej wybierane przez respondentów to Slice $(1,3 \%)$, Coca-Cola zero $(2,6 \%)$ i Coca-Cola light $(4 \%)$ (Tabela 2). Dwie pierwsze $\mathrm{z}$ nich to nowości produktowe w kategorii napojów gazowanych. Respondenci spożywają je najczęściej w celu ugaszenia pragnienia (53\%) lub ponieważ lubią ten smak $(30,5 \%)$. Ulubiony smak to smak coli (44\%) oraz smak pomarańczowy (32\%), a najmniej preferowany smak oranżady $(2,4 \%)$.

Z przedstawionych powyżej wyników badań można wysnuć pewne wnioski, mając jednak na uwadze fakt, iż poszczególne marki w różnym stopniu są dostępne na rynku. Zebrane dane wskazują, że respondenci uczestniczący w badaniach i deklarujący spożywanie napojów gazowanych, w dużej mierze należą do grupy tradycjonalistów. Najczęściej wybierają oni znane, sprawdzone i cieszące się renomą marki napojów, jak np. Coca-Cola i Pepsi. Jedynie w znikomym stopniu są oni otwarci na nowości smakowe i wykazują się dużą praktycznością. Wybierają głównie napoje w butelkach typu PET (79\% respondentów) o pojem- 
ności $0,51(53 \%)$ tj. małe (a przez to lekkie) i nietłukące się opakowania, które łatwo jest zakręcić i zabrać ze sobą.

Zgodnie z wynikami badań, aż 90\% respondentów zadeklarowało, że pije wody mineralne, przy czym najczęściej wybierane marki to Żywiec Zdrój (ponad 47\% ankietowanych), Kropla Beskidu (45\%), Nałęczowianka (31\%), Cisowianka (ponad 23\%) i Muszynianka (prawie 17\%). Najrzadziej natomiast spożywane marki wód mineralnych to Złoty Potok ${ }^{3}$ (0\%), Wysowianka (2,2\%) i Saguaro (2,2\%) (Tabela 3).

Jako okoliczności, w których zazwyczaj spożywane są wody mineralne, respondenci najczęściej wybierali stwierdzenia: ,aby ugasić pragnienie”(ponad 73\%) oraz „woda mineralna jest zdrowa" (23\%). Niemal 53\% respondentów deklaruje, że pije wody mineralne niegazowane, $31 \%$ wody mineralne gazowane, a 22\% wody smakowe, zwykle w butelkach $1,51(81 \%$ respondentów).

Tab. 3. Preferencje konsumentów dotyczące marek spożywanych wód mineralnych

\begin{tabular}{|l|c|c|}
\hline \multirow{2}{*}{$\begin{array}{c}\text { Marki wód mineralnych } \\
\mathrm{N}=180\end{array}$} & Liczność & Procent przypadków* \\
\cline { 2 - 3 } & 81 & 45,0 \\
\hline Kropla Beskidu & 85 & 47,2 \\
\hline Żywiec Zdrój & 42 & 23,3 \\
\hline Cisowianka & 5 & 2,8 \\
\hline Górska Natura & 30 & 16,7 \\
\hline Muszynianka & 56 & 31,1 \\
\hline Nałęczowianka & 7 & 3,9 \\
\hline Grodziska & 15 & 8,3 \\
\hline Kryniczanka & 28 & 15,6 \\
\hline Piwniczanka & 9 & 5,0 \\
\hline Arctic & 9 & 5,0 \\
\hline Ustronianka & 4 & 2,2 \\
\hline Wysowianka & 4 & 2,2 \\
\hline Saguaro & 5 & 2,8 \\
\hline Oaza & 0 & 0,0 \\
\hline Złoty Potok & 371 & 211,1 \\
\hline Razem & & \\
\hline
\end{tabular}

*Z uwagi na fakt, iż każdy z respondentów miał możliwość udzielenia trzech odpowiedzi, a w pewnych przypadkach nie udzielono żadnej odpowiedzi, suma wartości w kolumnie „procent przypadków” nie jest równa 100

Źródło: badania własne na podstawie programu STATISTICA 9

Respondenci deklarujący spożywanie wody mineralnej, podobnie jak to miało miejsce w przypadku kategorii napojów gazowanych, przede wszystkim wybierają powszechnie zna-

${ }^{3}$ Zakład wybudowany w miejscowości Złoty Potok, będącej sercem Parku Krajobrazowego Jury Krakowsko-Częstochowskiej. 
ne, cieszące się uznaniem marki jak Żywiec Zdrój czy Kropla Beskidu. Mniej znana marka Złoty Potok, Wysowianka czy Saguaro (marka Lidla) nie spotkała się z uznaniem respondentów (być może z uwagi na mniejszą dostępność tych produktów na rynku).

Ankietowani zapytani o opinię na temat kategorii napojów energetycznych i izotonicznych w przeważającej większości stwierdzili, że napoje te są niezdrowe (aż 48\% badanych), że są smaczne $(27 \%)$ oraz że są skuteczne $(25 \%)$.

Respondenci deklarujący spożywanie napojów energetycznych i izotonicznych stanowili 45\% badanej grupy. Najczęściej wybierali oni znane marki takie jak: Tiger (ponad 74\%), Powerade (prawie 68\%), Red Bull (prawie 37\%). Dużym powodzeniem cieszą się również nowe marki takie jak Black (ponad 34\%), Oshee (ponad 24\%), Green-up (prawie 18\%) oraz 4 move (prawie $8 \%$ ) (Tabela 4).

Tab. 4. Preferencje konsumentów dotyczące marek spożywanych napojów energetycznych i izotonicznych

\begin{tabular}{|l|c|c|}
\hline \multirow{2}{*}{$\begin{array}{c}\text { Marki napojów energetycznych } \\
\text { i izotonicznych N=90 }\end{array}$} & Liczność & Procent przypadków* \\
\cline { 2 - 3 } & 61 & 67,8 \\
\hline Powerade & 22 & 24,4 \\
\hline Oshee & 7 & 7,8 \\
\hline 4 move & 33 & 36,7 \\
\hline Red Bull & 67 & 74,4 \\
\hline Tiger & 31 & 34,4 \\
\hline Black & 14 & 15,6 \\
\hline Burn & 23 & 25,6 \\
\hline Mountain Dew & 7 & 7,8 \\
\hline Adrenaline Mountain Dew & 6 & 6,7 \\
\hline R20+ & 16 & 17,8 \\
\hline Green-up & 2 & 321,1 \\
\hline Inferno & 289 & \\
\hline Razem & & \multicolumn{2}{|c|}{. } \\
\hline
\end{tabular}

* Z uwagi na fakt, iż każdy z respondentów miał możliwość udzielenia trzech odpowiedzi, a w pewnych przypadkach nie udzielono żadnej odpowiedzi, suma wartości w kolumnie „procent przypadków” nie jest równa 100

Źródło: badania własne na podstawie programu STATISTICA 9

Określając okoliczności, w których zazwyczaj spożywane są napoje energetyczne i izotoniczne, respondenci najczęściej wybierali stwierdzenia: „po wysiłku fizycznym” (prawie $48 \%$ ) oraz ,po nieprzespanej nocy” (ponad 32\%).

Uzyskane wyniki badań wskazują, że konsumenci deklarujący spożywanie napojów energetycznych i izotonicznych mogą zostać zaliczeni do grupy pionierów i wczesnych naśladowców. Są oni otwarci na innowacje i chętnie wybierają nowości produktowe pojawiające się na rynku. Dodatkowym uzasadnieniem tej konkluzji może być fakt, iż rynek napojów energetycznych i izotonicznych jest stosunkowo nowym, choć intensywnie się rozwijają- 
cym, jednak posiadającym niewielki udział w całości, segmentem rynku napojów bezalkoholowych.

\section{ANALIZA MOTYWÓW WYBORU OKREŚLONEJ MARKI PRODUKTU}

Punktem wyjścia analizy wszelkich zachowań konsumentów, co potwierdzają modele ich zachowań, są motywy, jakimi kierują się oni w dokonywanych przez siebie wyborach. Mając to na uwadze istotne wydaje się dokonanie analizy motywów, którymi kierowali się respondenci przy wyborze konkretnych marek produktów w badanych segmentach rynku.

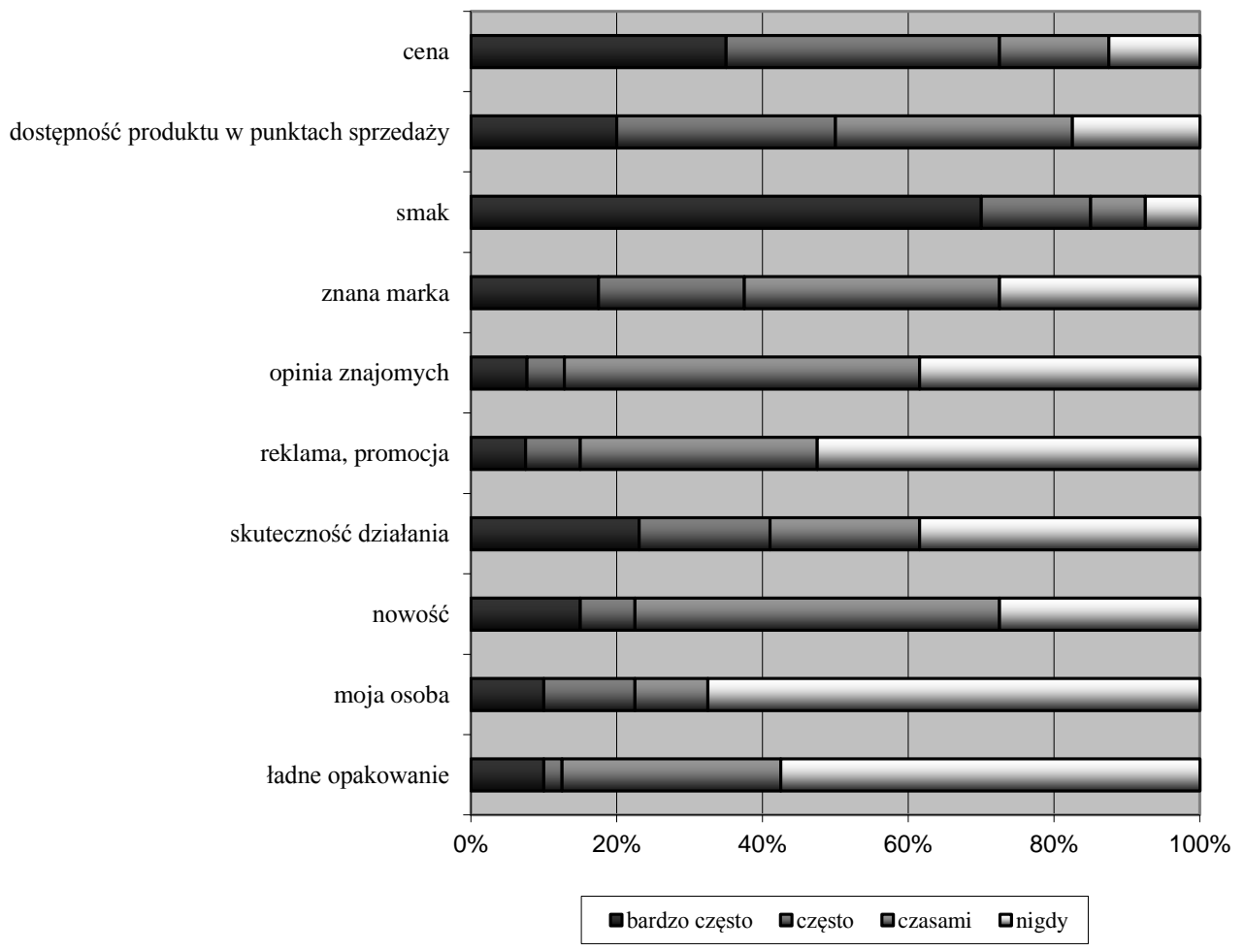

Rys. 1. Struktura odpowiedzi w odniesieniu do motywów wyboru napojów

Źródło: badania własne na podstawie programu STATISTICA 8

Na rysunku 1 przedstawiono deklaracje respondentów co do motywów, którymi kierują się kupując określone marki napojów bezalkoholowych.

Zarówno rysunek 1 prezentujący motywy respondentów w ujęciu procentowym jak również wykres ramka-wąsy (rys. 2) informują, że głównym motywem wyboru określonej marki napojów bezalkoholowych jest smak. Respondenci w tej kwestii byli bardzo zdecydo- 
wani i aż $85 \%$ badanych potwierdziło, że bardzo często lub często przy wyborze kieruje się właśnie tym motywem. Mediana dla tego motywu wynosiła 4.

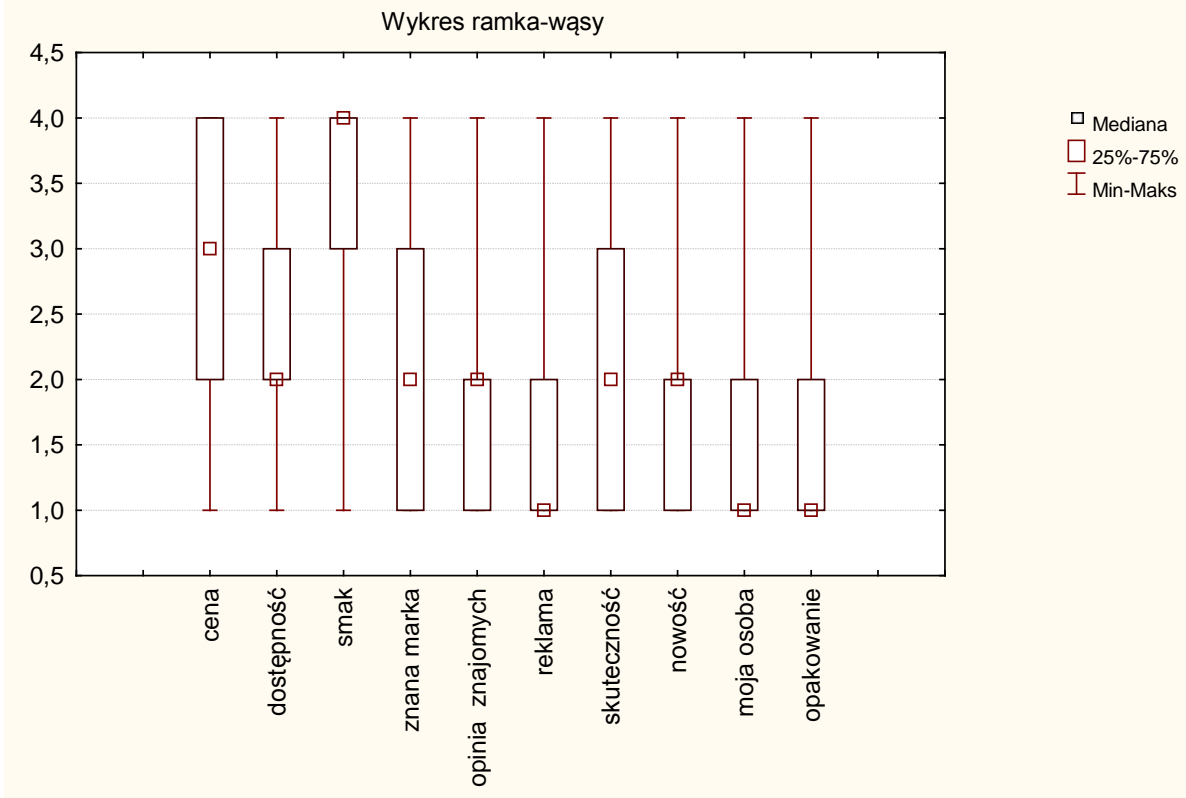

Rys. 2. Wykres ramka-wąsy w odniesieniu do motywów wyboru określonej marki napojów bezalkoholowych

Źródło: badania własne na podstawie programu STATISTICA 8

Nieco mniej istotnym motywem okazała się być cena. Ponad $72 \%$ ankietowanych zadeklarowało, że w swoich wyborach przede wszystkim kieruje się ceną. Bardzo rozciągnięta ramka w tym przypadku świadczy o tym, że zdanie poszczególnych ankietowanych w zakresie istotności ceny było bardzo różne. Mediana w tym przypadku wynosiła 3. Kolejnym istotnym motywem okazała się być dostępność produktu w punktach sprzedaży. Aż 50\% badanych odpowiedziało, że ten czynnik jest istotny przy wyborze produktu. Mediana dla tego motywu wynosiła 2. Natomiast najrzadziej przy wyborze respondenci kierowali się reklamą i promocją (15\%, mediana 2), ładnym opakowaniem (12,5\%, mediana 1$)$ i opinią znajomych $(12,5 \%$, mediana 1$)$.

Na rysunku 3 przedstawiono rozkład odpowiedzi będących ustosunkowaniem się respondentów do podanych w kwestionariuszu ankiety stwierdzeń zawierających postawy respondentów wobec innowacji produktowych. Innowacje te dotyczyły zarówno nowych marek, jak również nowych smaków napojów pojawiających się na rynku napojów bezalkoholowych w Polsce. 
kupuję znane, sprawdzone marki napojów, ponieważ jestem pewien ich jakości i smaku

kupuję nieznane mi wcześniej marki produktów, ponieważ lubię eksperymentować

kupuję klasyczne smaki napojów, ponieważ wiem jak smakują

kupuję pojawiające się na rynku nowe smaki napojów, ponieważ lubię zmiany

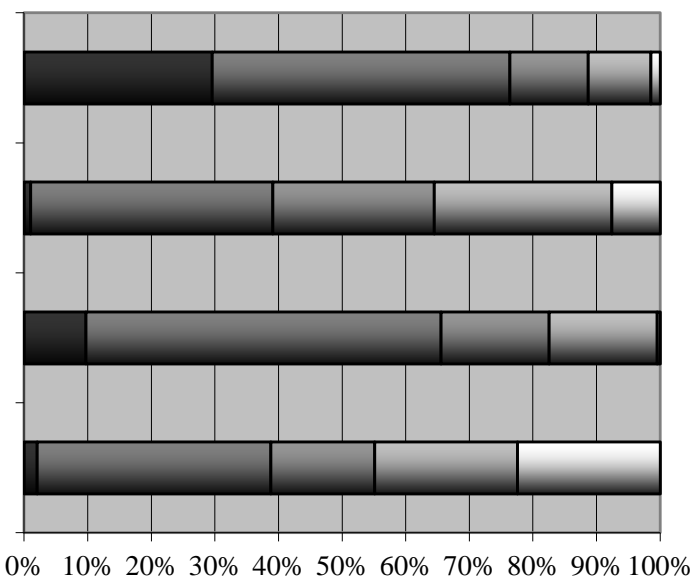

\begin{tabular}{|c|c|c|c|c|}
\hline Ezdecydowanie tak & 口tak & 口nie mam zdania & anie & Qzdecydowanie nie \\
\hline
\end{tabular}

Rys. 3. Postawy konsumentów wobec innowacji produktowych na rynku napojów bezalkoholowych

Źródło: badania własne na podstawie programu STATISTICA 8

Zgodnie z wynikami badań aż 77\% respondentów deklaruje, że kupują głównie znane marki napojów, ponieważ pewni są ich jakości oraz walorów smakowych. Nieco ponad $67 \%$ ankietowanych stwierdza, że wybierają przede wszystkim klasyczne smaki napojów, ponieważ znają ich smak. Smak okazał się również głównym motywem wyboru, co potwierdziło $85 \%$ respondentów (rysunek 1 i 2 ).

Wśród badanych znalazła się jednak również spora grupa osób (ponad 47\%), które decydują się na zakup nowych smaków napojów gdyż lubią zmiany. Natomiast grupa ponad $38 \%$ respondentów zadeklarowała, że kupuje nieznane wcześniej marki napojów, ponieważ lubi eksperymentować.

Podsumowując, analiza uzyskanych danych pozwala stwierdzić, iż konsumenci dokonując wyboru określonej marki produktu najczęściej kierują się smakiem, ceną oraz dostępnością określonego produktu w punkcie sprzedaży. W mniejszym stopniu istotne jest dla nich, czy określony produkt jest nowością. Natomiast najmniej istotnym motywem okazała się być reklama i promocja, ładne opakowanie czy opinia znajomych.

Generalnie respondenci uczestniczący w badaniach preferują znane i cieszące się dużą renomą marki napojów oraz klasyczne i sprawdzone smaki napojów. Wśród badanych znalazła się jednak również dość spora grupa pionierów, którzy lubią zmiany, nie boją się eksperymentować i nieustannie poszukują kolejnych nowości. 


\section{ZAKOŃCZENIE}

Zdaniem P. Druckera (Drucker 1992) celem biznesu jest stwarzanie klienta poprzez marketing i innowacje. Zadaniem marketingu jest zaspokajanie istniejących potrzeb klientów. Natomiast innowacje idą o krok dalej. Ich celem jest zaspokajanie przyszłych potrzeb. Innowacja nie jest nauką lub technologią, ale wartością użytkową, którą mierzy się jej wpływ na otoczenie. Innowacyjność powinna stać się obecnie zasadniczą siłą każdej organizacji i powinna być wpisana na trwałe w jej system zarządzania i kulturę. Jest to podstawowy warunek efektywnego funkcjonowania przedsiębiorstw w gospodarce rynkowej.

Owa innowacyjność odgrywa szczególną rolę na rynku napojów bezalkoholowych, który był przedmiotem analiz w niniejszym opracowaniu. Jak już wcześniej wspomniano typową cechą produktów tego rynku jest szybka rotacja oraz relatywnie niski koszt produkcji, a konsumenci dokonując codziennych zakupów muszą dokonywać wyboru produktów spośród szerokiej gamy dostępnych na rynku napojów bezalkoholowych.

Szczegółowa analiza zebranych w toku badań danych statystycznych pozwala stwierdzić, iż respondenci dokonując wyboru określonej marki napoju najczęściej kierują się jego smakiem, ceną oraz dostępnością w punkcie sprzedaży.

Ankietowani deklarujący spożywanie napojów gazowanych i wody gazowanej okazali się być raczej tradycjonalistami i wybierali przede wszystkim znane i cenione marki napojów (Pepsi, Coca-Cola, Kropla Beskidu, Żywiec Zdrój). W mniejszym stopniu byli oni otwarci na nowości produktowe (być może z uwagi na zróżnicowany poziom ich dostępności w poszczególnych punktach handlowych). Natomiast grupa respondentów deklarujących picie napojów energetycznych i izotonicznych poza od dawna istniejącymi już markami napojów (Tiger, RedBull) często wybierała również nowości produktowe jak np. Black (firmy FoodCare) czy Green-up (Herbapolu). Wśród badanych znalazła się więc jednak również pewna grupa pionierów, którzy lubią zmiany, nie boją się eksperymentować i poszukują kolejnych nowości.

Należy tu również zaznaczyć, że tego typu działania jak poszerzanie portfolio produktowego przedsiębiorstwa, zmiana i uatrakcyjnianie wyglądu opakowania, wprowadzanie limitowanych serii produktowych z pewnością zwiększają udział przedsiębiorstwa w rynku oraz utrwalają świadomość istnienia marki w umysłach konsumentów.

\section{Literatura}

Bogdaniecko J. (red.), 2004, Innowacyjność przedsiębiorstw, Wydawnictwo UMK, Toruń.

Drucker P.F., 1992, Innowacja i przedsiębiorczość. Praktyka i zasady, PWE, Warszawa.

Grandstrand O., 1999, The Economics and Management of Intellectual Property. Towards Intellectual Capitalism, Edward Elgar, Cheltenham.

Griffin R.W., 1996, Podstawy zarzadzania organizacjami, Wydawnictwo Naukowe PWN, Warszawa. Grudzewski W.M., Hejduk I.K., 2004, Metody projektowania systemów zarządzania, Difin, Warszawa. Hamel G., Prahalad C.K., 1999, Przewaga konkurencyjna jutra, Business Press, Warszawa.

Janasz W., Kozioł K., 2007, Determinanty działalności innowacyjnej przedsiębiorstw, PWE, Warszawa. Kay J., 1996, Podstawy sukcesu firm, PWE, Warszawa.

Kotler Ph., 1994, Marketing. Analiza, planowanie, wdrażanie i kontrola, Gebethner i Ska, Warszawa. 
Pałucha K., Współczesne metody wspomagające zarządzanie produkcją, „Kwartalnik Naukowy Organizacja i Zarządzanie", 2/2008.

Porter M.E, 1990, The Competetive Advantage of Nations, The Macmillan Press Ltd., London.

Porter M., 2001, Porter o konkurencji, PWE, Warszawa.

Schumpeter J., 1960, Teoria rozwoju gospodarczego, PWN, Warszawa.

Simon H., 1999, Tajemniczy mistrzowie. Studia przypadków, Wydawnictwo Naukowe PWN, Warszawa.

Wiszniewski W., 1999, Innowacyjność polskich przedsiębiorstw przemystowych, Wydawnictwo Instytut Organizacji i Zarządzania w Przemyśle „Orgmasz”, Warszawa.

\section{Strony internetowe}

Krajowa Izba Gospodarcza „Przemysł Rozlewniczy”, Packaging Polska, styczeń 2011, www.packaging-polska.pl/pg/pl/rozne/opakowania_spozywcze/plynna_analiza_rynek_napojow.html

Rutkowski W., 2010 r. w przemyśle rozlewniczym wód w opakowaniach i napojów bezalkoholowych, Krajowa Izba Gospodarcza „Przemysł Rozlewniczy”, www.plastech.pl/wiadomosci/artykul_4273_5/2010-r-w-przemysle-rozlewniczym-wod-w-opakowaniach-i-napojow-bezalkoholowych

Sulejewicz A., Innowacje jako dziedzina gospodarowania, [w:] Określenie istoty pojęć: innowacji $i$ innowacyjności ze wskazaniem aktualnych uwarunkowań $i$ odniesień do polityki proinnowacyjnej - podejście interdyscyplinarne, Krajowa Izba Gospodarcza, www.kig.pl/assets/upload/ Opracowania\%20i\%20analizy\%20/Innowacyjnosc.pdf

www.stat.gov.pl/cps/rde/xbcr/gus/PUBL_NTS_dzialalnosc_innowacyjna_2004-2006.pdf

\section{Product innovation of production enterprises and consumer preferences}

Nowadays, the overriding aim of each enterprise is to satisfy consumers' needs and to generate profits. Usually, companies realise these aims by having a wide-variety-of-products portfolio, and by using adequate marketing strategies or sale techniques. What is extremely important in this field is product innovation and adjusting the range of products to market needs.

Innovation is especially important on the soft drinks market, which is the focus of the article. The typical feature of this market is fast moving of products, low production costs and a great variety of products accessible on the market. These factors cause that the soft drinks market is very demanding and competitive.

Dr Anna Irena Szymańska

Uniwersytet Pedagogiczny w Krakowie

Instytut Geografii

Zakład Przedsiębiorczości i Gospodarki Przestrzennej

e-mail: szymanskaa@o2.pl 